\title{
The Evolution of Mediation in Central Asia: The Perspective of the European Bank for Reconstruction and Development
}

\author{
Marie-Anne Birken and Kim O’Sullivan*
}

\begin{abstract}
The practice of mediation dates back to very ancient times and was part of early Roman law. Mediators existed in many cultures, and often overlapped with the roles of traditional wise men and tribal chiefs. The settlement of disputes through mediation is also part of Confucian and Buddhist history in the belief that conflicts must be resolved peacefully to maintain the natural harmony of life and avoid losing respect of others. Although mediation, as a formal process for alternative dispute resolution, was more recently developed in Anglo Saxon countries and is now increasingly widespread in common law jurisdictions, it is equally suitable for countries with civil law traditions. This chapter considers the practice of mediation in Central Asia, specifically the Commonwealth of Independent States countries, and reports on the European Bank for Reconstruction and Development's support for the development of mediation in that region. There is a perception that countries are less receptive to mediation than other countries because of their post-Soviet legacy, although the legal traditions of these countries include a number of out-of-court resolution mechanisms similar to mediation, even during the Soviet era. In any event, at a time when courts are under ever-increasing time and resource pressures, flexible dispute resolution processes are required that transcend national systems; be they of a common or civil law cultural tradition.
\end{abstract}

* Marie-Anne Birken, General Counsel, European Bank for Reconstruction and Development (EBRD), birkenm@ebrd.com; Kim O'Sullivan, Senior Counsel, EBRD’s Office of the General Counsel, osullik@ebrd.com. The contents of this publication reflect the opinions of individual authors and do not necessarily reflect the views of the EBRD. Terms and names used in this chapter to refer to geographical or other territories, political and economic groupings and units, do not constitute and should not be construed as constituting an express or implied position, endorsement, acceptance or expression of opinion by the EBRD or its members concerning the status of any country, territory, grouping and unit, or delimitation of its borders, or sovereignty.

(C) ASIAN INFRASTRUCTURE INVESTMENT BANK (AIIB), 2019 | DOI:10.1163/9789004407411_014

This is an open access chapter distributed under the terms of the CC-BY-NC 4.o License, 
In its Model Law on International Commercial Conciliation (2002), the United Nations defines mediation as:

[the process] whereby parties request a third person or persons to assist them in their attempt to reach an amicable settlement of their dispute arising out of or relating to a contractual or other legal relationship. The mediator does not have the authority to impose upon the parties a solution to the dispute. ${ }^{1}$

The fact that parties are not bound by the outcome of mediation allows them to approach a claim more holistically, taking ownership of the outcome of a case and potentially even solving problems beyond its subject matter. Greater investment in the process by the parties to the dispute may in turn correlate to higher settlement rates, as seen in Belarus, for example, where compliance with mediation agreements has been estimated by local experts at between 80 and $90 \%$ in $2016 .{ }^{2}$ While equivalent statistics on consensual submission to court orders are not available in Belarus, it can be assumed that the number of litigants forced to rely upon bailiffs and other enforcement tools is considerably higher than the corresponding $10-20 \%$ of participants in mediation. It is also worth noting that the $80-90 \%$ figure is comparable to success rates for mediation in the United Kingdom. ${ }^{3}$

Mediation's perceived benefits include greater control over the negotiation process when compared to court proceedings and decisions, which are difficult to predict. Its results-focused approach and the elimination of the oppositional nature of a court room may also contribute to greater pragmatism and the preservation of business relations post conflict. As has been said,

Mediation is largely about putting the past behind you and focusing on what's best going forward. It won't necessarily give you 'justice' or decide

1 UnCitral, Model Law on Commercial Conciliation with Guide to Enactment and Use 2002, art. 1(3); the Oxford English Dictionary defines 'Mediate' as 'Intervene in a dispute in order to bring about an agreement or reconciliation', English Oxford Living Dictionaries, <https:// en.oxforddictionaries.com/definition/mediate > last accessed 25 February 2019.

2 Vilasova Mikhel \& Partners, 'Mediation (Медиация)'.

3 In its regular mediation audits, the UK Centre for Effective Dispute Resolution (CEDR) notes settlement rates of $86-90 \%$ over the period $2007-2016$. 
who's right and who's wrong, but it will give you the chance to find a resolution and to move on. ${ }^{4}$

Cost efficiency is often mooted as a benefit of mediation. The Centre for Effective Dispute Resolution (CEDR) in the UK, in its Eight Mediation Audit (2018), estimates that, for the period 1990-2018, the early resolution by mediation of cases that would otherwise have proceeded through litigation has saved UK businesses $£ 28$.5 billion (pounds sterling) in wasted management time, damaged relationships, lost productivity and legal fees. ${ }^{5}$ They might also have mentioned the freeing up of legal contingencies on a company's balance sheet for revenue-generating activities.

Policy-makers are also attracted to the cost benefits of alternative dispute resolution (ADR). In his keynote speech at the Civil Mediation Conference in May 2014, Lord Faulks QC observed that the Dispute Resolution Commitment launched by the UK Government in 2011, together with its predecessor, the ADR Pledge, made by the Lord Chancellor, Lord Irvine, in March 2001, both requiring government departments and agencies to use ADR to resolve their own legal disputes which might otherwise lead to a court or tribunal hearing, have saved taxpayers at least $£ 400$ million (pounds sterling). ${ }^{6}$

There are significant time advantages to mediation. All forms of dispute resolution will of course require preparation but, once the parties engage, a mediation can be completed in just days or weeks whereas court cases typically take months or years. When the European Bank for Reconstruction and Development (EBRD) first piloted mediation in Moldova in 2013, it took on average nine days to settle a claim through mediation compared to the average 420 days taken to litigate a case. ${ }^{7}$

There is good evidence that mediation is a more gender neutral form of dispute resolution than taking disputes to court. In addition to being both cheaper and more rapid (both of which are beneficial for women-owned businesses that are generally smaller), mediation is a more amicable and less confrontational way of resolving a dispute when compared to filing a lawsuit. ${ }^{8}$ Women also favour mediation as a new occupation. EBRD's experience to date has shown that women tend to outnumber men on the mediation training courses that the EBRD conducts in countries of its operation. In Moldova,

4 Levitt, 'Mediate Not Litigate to Trim the Bills' 11 December 2013.

5 CEDR, 'The Eighth Mediation Audit', 10 July 2018.

6 Faulks, 'Mediation and Government', 19 June 2014.

7 CEDR, 'Mediation in the Moldovan Courts'.

8 'Report on the Context Tajikistan', 35. 
for example, $57 \%$ of the participants in the EBRD's mediation training were women. ${ }^{9}$ Of course, that does not, of itself, translate into greater success in dispute resolution for women-owned businesses. For example, in Mongolia, 15 mediators who received international mediation certification under an EBRD project, more than half were women. But of 80 cases submitted to commercial mediation during the period that followed, only a very small handful involved businesses led by women..$^{10}$ Nevertheless, the case is clear for mediation as a less costly, time-consuming and confrontational form of dispute resolution, one that is more likely to allow the protagonists to maintain cordial ongoing business relations by putting the dispute behind them and moving forward.

\section{The Evolution of Alternative Dispute Resolution in Central Asian Countries}

Before turning to the recent development of mediation specifically, the evolution of alternative dispute resolution in Central Asia, and specifically Commonwealth of Independent States (CIS) countries should be considered more generally first. ${ }^{11}$ The existence of a Soviet legal framework, which encouraged various out-of-court dispute resolution mechanisms, undermines any scepticism that disputants were discouraged from seeking out-of-court assistance and also that forms of ADR do not already have a basis in, and cannot be integrated into, the legal frameworks of cis countries.

The Principles of Civil Procedure of the USsR and the Union Republics envisaged both community courts (tovarishcheskie sudy) and arbitral tribunals (treteiskie sudy) as alternatives to traditional state court proceedings. ${ }^{12}$ Community courts were dispute resolution bodies created outside the regular court system, usually within an enterprise or organisation, to resolve the small claims or employments claims of the enterprise. ${ }^{13}$

Arbitral tribunals were introduced as early as 1917 and operated on an ad hoc basis. ${ }^{14}$ Disputing parties were free to elect state-approved judges, hearings

9 UNDP, 'Final Project Implementation Report Phase 2' 2018, 3.

10 Mongolia BTOR, p. 8.

11 The Commonwealth of Independent States was formed on 8 December 1991 and currently consists of nine members states: Armenia, Azerbaijan, Belarus, Kazakhstan, the Kyrgyz Republic, Moldova, Russian, Tajikistan, Uzbekistan and one associate state: Turkmenistan.

12 The Principles of Civil Procedure of the UssR and the Union Republics, art 4.

13 Decree on Community Courts.

14 Decree of the Council of People's Commissars on Courts, art 6. 
were free and open to the public (primarily for educational purposes) and decisions were directly enforceable. ${ }^{15}$ However, the list of pre-selected judges able to preside on an arbitral tribunal contributed to the tribunal's lack of popularity, as the list offered limited choice of judges and these were selected by the state based on unclear criteria. Additionally, lack of privacy further reduced the appeal of arbitration as a court alternative.

Today, arbitral tribunals continue to operate in cis countries. They are akin to a form of private arbitration and are used primarily for business disputes. Both parties must agree to submission to the treteiskie sudy instead of a state court and must pay associated costs, including arbitrators' fees. The decisions of the treteiskie sudy are final and appeal can be made to the arbitrazh courts (commercial courts which would otherwise hear such cases) for enforcement without a revisiting of the substance of the case.

With a view to reducing the incidence of cases brought before statesponsored courts in the 1980s, the Soviet legislature introduced a pre-court method of dispute resolution called pretension (pretenziia), being a mandatory attempt to settle a dispute between businesses by exchange of letters. ${ }^{16}$ The legislation specifically required enterprises whose property rights had been violated to send a written pretension to the alleged offender who was obliged in turn to produce a response within a designated period of time, failing which a claim could be lodged in court.

The pretension pre-court method of dispute resolution may have laid the foundations for the pre-trial dispute settlement procedure. The latter became mandatory for commercial court proceedings in Russia further to an amendment to the Russian Arbitrazh Procedure Code effective from 1 June 2016. ${ }^{17}$ This procedure requires a claimant to send a demand letter to the defendant and wait for the expiry of 30 calendar days before filing a claim with the $a r b i$ trazh court. The expectation is that the parties will explore the potential for resolving the dispute through means of ADR during that 30-day period.

Disputes between Soviet enterprises falling under different ministries were resolved by gosarbitrazh (state arbitration). ${ }^{18}$ This was a quasi-judicial body formed in 1931. It was originally responsible to the Council of Ministers and was later (1954) assumed by the Ministry of Justice. Its scope included disputes arising from breach of contract, non-contractual obligations (for example the

\footnotetext{
15 Civil Procedure Code of the Russian Soviet Socialist Republic, art 338.

16 Rules on Commercial Cases Hearing by State Arbitrations.

17 Arbitration Procedure Code of the Russian Federation.

18 Sheridan $1955,474-83$.
} 
value of assets being transferred from one ministry to another), torts causing damage and money paid and received.

It is notable that state arbitration was also the forum used for resolving socalled pre-contract disputes, being disagreements between two state enterprises on the terms of a proposed contract between them. In considering such pre-contract disputes referred to state arbitration, arbitrators would consider the whole contract, correcting illegalities or ambiguities and adding essential terms as necessary. They were guided not only by the interests of the parties before them but also by the general interests of the community.

One particular feature of disputes resolved by state arbitration was the socalled conciliation principle. It was prescribed by law and required a judge to encourage the parties to reach an agreement on the dispute and then adjudicate the case based on this agreement. In the context of family disputes, parties would often try to reach an amicable settlement of a dispute, during any phase of the court process. But within commercial disputes this would be a rare occurrence.

In many traditional societies in the cIs countries, for example in the Kyrgyz Republic, private disputes are sometimes referred to aksakals, which literally means 'white beards'. Historically, they are persons of a certain age who command high respect and trust in a community. A special presidential decree announced in 1995 ordered the revitalisation of aksakal courts in the Kyrgyz Republic with jurisdiction over property, torts and family law. Access to these services is free. Encouraged in part as a rekindling of Kyrgyz national identity and a reconnection with the country's nomadic past, aksakal courts are widespread and well established. In 2006 there were approximately 1,00o aksakal courts functioning in the Kyrgyz Republic. ${ }^{19}$ While the system is court-based, aksakals are often considered to be mediators. This is perhaps because they resolve disputes beyond their primary subject matter and also provide restorative, educational services.

\section{The Development of Mediation in the Post-Soviet Period}

While there are historical examples of quasi-mediation procedures in various Soviet republics, and indeed across the Soviet Union, mediation in its modern form only began to find traction in the Soviet space during the late $1980{ }^{20}{ }^{20} \mathrm{It}$ was at this time that, in the wake of breakdowns in industrial relations and

\footnotetext{
19 Beyer 2006.

20 'Conference Materials-Modern Practice of Mediation'.
} 
subsequent strikes, United States mediators were invited to give seminars on mediation and conflict resolution in the industrial coal-mining region of what was then Ukraine Soviet Socialist Republic. ${ }^{21}$ By the 199os, mediation enthusiasts were at the forefront of promoting mediation in the newly independent post-Soviet countries. They established private mediation centres, whose work focused on the creation of public trust in the profession. ${ }^{22}$ In Russia, for example, the National Organization of Mediators was founded to help establish a professional community of mediators. ${ }^{23}$

These initiatives were supported by developments aimed at the transfer of the peaceful settlement of disputes from a court-administered process to one implemented by out-of-court mediators. In Belarus, for example, prior to 2011, the Commercial Procedure Code would only allow the appointment of conciliators from among commercial court officials. Amendments to the code in 2011 allowed the involvement of out-of-court mediators for the first time. ${ }^{24}$

The impact of developments such as this cannot be overstated. The combined effect of overwhelming confidence in the State and a general lack of trust for private initiatives, creating an effective monopoly for administrative means of dispute resolution, is gradually diluted by the resolution of disputes being placed in the hands of independent private entities. More recently, Russia has been particularly active in promoting mediation since 2010. This policy shift was driven in part by a desire to reduce the growing backlog of cases (several million on hold) in the country's courts. New legislation was passed, and institutions strengthened. ${ }^{25}$

Looking further afield, the legislative picture across the cIs countries is mixed. Belarus, Kazakhstan, Moldova and Russia have enacted separate laws on mediation. The Kyrgyz Republic did the same in February 2018 and a law on mediation has been signed by the president of Uzbekistan ready to take effect in 2019. By contrast, the laws of Armenia, Azerbaijan and Tajikistan do

\footnotetext{
21 Kyselova 2017, 108.

22 'Report on the Context Tajikistan', 16.

23 'State of Mediation in Russia'.

24 'Analysis of the Experience of Meditative Practice'.

25 Federal Law No $193-\mathrm{FZ}$ 'On the alternative dispute resolution procedure involving mediator (mediation procedure)' was passed in 2010. In 2014, the Russian Supreme Court issued a report on applying the federal mediation law. Also in 2014, Russia was the first country in the world to recognise mediator as a profession with professional standards approved by the Ministry of Labour and Social Development (Order of 15 December 2014, No 1041n).
} 
not yet encompass mediation. It should be stressed that a law specifically on mediation is not necessarily required to kick-start or permit the development of mediation in a given jurisdiction. Indeed, neither Tajikistan nor Georgia yet has a mediation law on the statute books. Nevertheless, civil procedure rules in both jurisdictions oblige the courts to recommend that the parties to a dispute seek the assistance of a mediator.

Yet, while a specific law on the subject need not be a pre-requisite to the development of mediation, the EBRD's experience is that such legislation serves to legitimise the practice in the eyes of businesses, the judiciary and legal advisers. Moreover, there is a useful promotional effect inherent in legislation directed specifically at mediation as a form of alternative dispute resolution.

\section{4 \\ E BRD's Work Promoting Mediation of Commercial Disputes in Central Asia}

The EBRD has long been at the forefront of legal reform in its countries of operation, and dispute resolution is one of its main areas of focus in this respect. Its work on dispute resolution includes judicial capacity within the mainstream court system, training judges on the interpretation and application of commercial law and bailiffs on the enforcement of court decisions. EBRD also spends considerable time on the development of alternative dispute resolution, including mediation. The EBRD, at the time of writing this chapter, is actively promoting mediation in three CIs countries: the Kyrgyz Republic, Moldova and Tajikistan.

\subsection{Tajikistan}

When the EBRD started its mediation work in Tajikistan, there was no law on mediation and no established mediation practice. An unsuccessful previous attempt had been made, by a working group comprising the judicial training centre, the Supreme Court and leading lawyers, to draft and promote a law on mediation. The EBRD brought the Chamber of Commerce and Industry into the project in order to work together on raising the profile of mediation as an option, increasing awareness among the general population and, especially, businesses.

The EBRD's next task was to support the establishment of a mediation centre at the Chamber of Commerce. With the input of EBRD's experts, there is now a draft law on mediation circulating among government stakeholders for 
comment before being presented to parliament. The ongoing follow-up will involve strengthening the mediation centre and training mediators.

\subsection{Kyrgyz Republic}

The position in the Kyrgyz Republic was somewhat more advanced than that in Tajikistan as the EBRD project began. A law on mediation had already been adopted. Accordingly, the EBRD's focus was on developing mediation in the country and facilitating successful implementation of the new law, predominantly by training mediators. In the first year of activity, more than twenty mediators were trained.

The following case study highlights some of the benefits of mediation over traditional litigation. One of the mediators trained through the EBRD programme reported a dispute involving business partners in the services sector. The parties were at odds over questions of professional ethics, commercial decisions and damage to the reputation of the business, none of which lends itself to resolution by a court. The accusations were of lying and disclosing confidential information. With the help of the mediator, the soon-to-be former partners resolved their differences in the space of six hours over two sessions. It was agreed that the party whose conduct had been questioned would leave the business and reimburse the other for the costs involved in re-registering their company in his own name. It is difficult to see how a court could have achieved that result at all, certainly not in two sessions.

\subsection{Moldova}

The EBRD has been working on mediation in Moldova since 2012. The work has involved training commercial mediators, establishing a mediation centre and raising awareness of mediation. The project team has recently been invited to work with litigants in the courts, explaining the benefits of mediation to them and offering mediation services in the court building.

One notable case involved a husband and wife who were also business partners. They had been trying for some time to agree on the division of their property, including houses, land plots and a bank account. The value of the claim was approximately US $\$ 30,000$. Another major case involved a large Moldovan glass manufacturing company (and also the EBRD's client) against the largest utility company in the country. The case resulted in amicable settlement saving both time and money. Before the case was referred to mediation by the court, it had been in litigation for some five months. The mediator resolved the dispute within seven days. This involved two private and two joint sessions. The assets were successfully divided and the parties avoided going through a full-blown 
trial. Overall, this court-referred mediation pilot resulted in some $15^{\circ}$ cases referred to mediation, 49 of which were subsequently settled. It took, on average, fewer than 14 days to settle these cases, which freed up over EUR30o,ooo of indirect benefits. ${ }^{26}$

\subsection{Regional}

Recognising the growth in interest in mediation, the EBRD worked with a leading international commercial mediator to organise a regional forum on commercial mediation in Eastern Europe and Central Asia. This event brought together representatives of 11 countries, among which were justice ministers, senior judges, leading commercial mediators and international experts. It was a wonderful opportunity to share experiences, learn from each other, develop thinking and build networks. There was a degree of uncertainty and healthy scepticism among delegates at the beginning of the event. Fair challenges were made to the experts based on cultural differences and perceptions. The healthy debate that ensued generated a good deal of enthusiasm, resulting in a joint communique which stressed the need to professionalise mediation in the CIS countries through increased cross-border co-operation.

\section{Considerations when Contemplating a Mediation Project in} Central Asia

It may be instructive to consider the topics that the EBRD's legal reform project teams would typically seek to explore through questioning, at the outset of a mediation project. What is the current position as borne out by the relevant statistics? How many commercial cases are mediated per year? How many commercial mediators have been trained to date and by whom? How many qualified mediators have training and experience in relevant subject areas such as commercial contracts, intellectual property rights and shareholder disputes?

What are the major obstacles to the development and growth of mediation (for example lack of credibility of the process, lack of credibility of mediators themselves, lack of public awareness, concerns about enforcing the outcome)? Does the jurisdiction already have a specific law on mediation? If not, is mediation explicitly contemplated elsewhere in legislation or civil procedure rules? And if there is no explicit reference to mediation anywhere in the country's

$\overline{26}$ UNDP, 'Final Project Implementation Report Phase 2' 2018, 5. 
legal system, is there a risk of challenge to its validity or of an argument that it is not permitted? Ultimately, while a specific law on mediation is not a prerequisite to the successful development of a mediation culture, it may be necessary to cut a path through the existing legislation that allows mediators to function freely.

Is the procedure of mediation regulated by law? If so, what does the law provide and in what ways does it restrict the freedom of the parties and the mediator to manoeuvre their way to a resolution? How do disputes end up in mediation? Do the courts have power to order parties to engage in mediation or at least encourage parties to use mediation? Where the courts have such powers, are they exercised on the basis of nationally-established criteria, or is the choice to order/encourage mediation in the sole discretion of the judge? Is there an established system of court-annexed mediation (where the judge or a third party nominated by her/him acts as mediator under the auspices of the court in which the dispute is already being heard)?

Are there any incentives provided by the State for those parties who elect to engage in mediation (for example a reduction in court fees)? Are there any penalties that can be imposed on parties who refuse to engage in mediation? Apart from by referral or order of the courts, how else do cases come to mediation (by the choice of the parties presumably but are there any others)?

Raising awareness of mediation is often the starting point but it does not suffice on its own. Even once aware of the possible benefits, potential parties to mediation will have concerns that need to be addressed. For example, as to confidentiality - both of the fact of the mediation itself and of the nature and content of the discussions. Also, related to confidentiality, is there a risk that the parties' discussions might subsequently be quoted in litigation proceedings? Mediation relies on a degree of openness and candour on the part of the parties. They will be wary of exposing themselves unduly if what they say can be played back to them as evidence in later court hearings.

How can agreements reached through mediation be enforced by the parties? Can they be enforced through the courts? Does the law allow such enforcement and, if it does in theory, has such enforcement been practised successfully? Are mediators regulated and, if so, how? For example, are they regulated by the Ministry of Justice, or some other body? Are they governed by a code of conduct, as to ethics or otherwise? Is the training and accreditation of mediators regulated by law? Are there minimum training standards, as to the number of days committed to training for example? Are mediators without accreditation permitted to practise as mediators?

How have lawyers and judges reacted to the introduction (or proposed introduction) of mediation? Do lawyers have concerns? If so, which and how have they been addressed? Is there a clear path for lawyers and judges to become 
mediators? Do lawyers encourage the use of mediation by including mediation clauses in commercial contracts? Is mediation introduced to students at law school? Is mediation limited to the court-annexed variety or does the private sector already play a role in commercial mediation? Are there private sector mediation schemes? Does the private sector promote mediation? Are stakeholders, including the government, supportive of private sector involvement?

In light of the foregoing, and the EBRD's overall experience of mediation in Central Asia, this final section affords a number of observation made by way of conclusion. Mediation can be introduced and developed in any jurisdiction, whether of a common or civil law tradition. While not essential, there is a benefit to enacting a law on mediation (and to using it to raise awareness among key stakeholders in the legal profession). It is important to raise awareness of arbitration among the general public with a focus on potential users of mediation services; its application is universal and need not be limited to business disputes. Mediators do not operate in competition with the legal profession. This perception should be firmly rejected. Instead, lawyers and law school students should be encouraged to see mediation as an option, for their clients and indeed for their own careers.

Mediation should be promoted by demonstration. It is important that highly trained local mediators who are well connected to the business community are seen to provide effective mediation services and resolve disputes. Court-annexed mediation is not unhelpful but does not take disputes out of the court system entirely. Lastly, private sector mediation (independent of the court system) should be supported and hosted by local chambers of commerce for example.

\section{Reference List}

'Analysis of the Experience of Meditative Practice of Countries of Near Foreign Countries', 'Анализ Опыта Медиативной Практики Стран Ближнего Зарубежья' $<$ http://fedim.ru/wp-content/uploads/2014/07/149-206.pdf > accessed 25 February 2019.

Beyer J, 'Revitalisation, Invention and Continued Existence of the Kyrgyz Aksakal Courts: Listening to Pluralistic Accounts of History' (2006) 38 The Journal of Legal Pluralism and Unofficial 141.

Centre for Effective Dispute Resolution, 'Mediation in the Moldovan Courts'. 
Civil Procedure Code of the Russian Soviet Socialist Republic.

'Conference Materials First Specialised International Conference-“Modern Practice of Mediation: Types, Technologies, Approaches”, 'Материалы конференции Первая Специализированная Международная конференция-«Современная Практика Медиации: Виды, Техники, Подходы»' <http://arbimed.ru/pervayaspecializirovannaya--mezhdu $>$ accessed 25 February 2019.

'Decree of the Council of People's Commissars on Courts' (1917) < http://www.hist.msu .ru/ER/Etext/DEKRET/o_sude1.htm > accessed 25 February 2019.

'Decree on Community Courts' (16 January 1965) < www.lawmix.ru/sssr/13651> accessed 25 February 2019.

EBRD, 'Moldova-Commercial Mediation and Arbitration' Project No. 65054.

Faulks Q C, 'Mediation and Government', (Gov.UK, 19 June 2014) <www.gov.uk/ government/speeches/mediation-and-government> accessed 25 February 2019.

'Federal Law No 193-FZ "On the alternative dispute resolution procedure involving mediator" (Mediation Procedure)' (27 July 2010) < http://mediators.ru/eng/about_ mediation/home_law/193-fz/> accessed 28 February 2019.

Kyselova T, 'Mediation in Ukraine: Challenges of Peace and War' (2017) 26 Tulane Journal of International \& Comparative Law $108<$ https://ssrn.com/abstract=3177543> accessed 25 February 2019.

Mongolia-Internal EBRD Country Visit Back to Officer Report, p. 8.

Order of the Ministry of Labour and Social Protection No. 1041n of December 15, 2014.

Oxford Dictionaries, 'mediate' (English Oxford Living Dictionaries) <https:// en.oxforddictionaries.com/definition/mediate $>$ accessed 25 February 2019.

'Principles of Civil Procedure of the USSR and the Union Republics' (1961) <http://xn-eraaejmenocxq.xn--prai/node/13893> accessed 25 February 2019.

Report on the Context, Needs and most effective ways to establish mediation mechanism in Tajikistan.

Roger levitt LLB, 'Mediate Not Litigate to Trim the Bills' (Roger Levitt Mediation) $<$ https://rogerlevittmediation.co.uk/roger-levitt-mediation-featured-in-the-timesnewspaper/> accessed 25 February 2019.

'Rules on Commercial Cases Hearing by State Arbitrations' (1980) < http://bestpravo .com/sssr/gn-normy/k4k.htm> accessed 25 February 2019.

Sheridan L A, 'Fraud and Surprise in Legal Proceedings' (1955) 18 The Modern Law Review 474.

'State of Mediation in Russia' <www.european-mediation.eu/pdfs/State\%2oof\% 2omediation\%20in\%2oRussia_brief\%202015[5].pdf > accessed 25 February 2019.

'The Arbitrazh Procedure Code of the Russian Federation No95-FZ', 'Арбитражный процессуальный кодекс Российской Федерации № 95-Ф3 от 24.07.2002 г. 
(с изменениями, внесенными в соответствии с Федеральным законом No 101-Ф3 от 28.05.2017 г.)' (amended on 24 July 2002) < http://www.consultant.ru/ document/cons_doc_LAW_3780o/> accessed 25 February 2019.

The Eighth Mediation Audit, available at: <www.cedr.com/docslib/The_Eighth_ Mediation_Audit_2018.pdf $>$ last accessed 25 February 2019.

UNCITRAL, Model Law on Commercial Conciliation with Guide to Enactment and Use 2002, (United Nations Publication 2004).

UN Development Programme 'Final Project Implementation Report: Moldova Phase 2' (2018).

Vlasova Michel \& Partners, 'Медиация', (Vlasova Michel \& Partners) <http://vmp.by/ practices/mediation/> accessed 25 February 2019. 